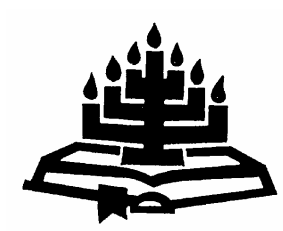

\title{
Diskoerse oor heling in 'n narratief- pastorale benadering
}

\author{
Julian Müller \& Jaco Putter1 \\ Praktiese Teologie \\ Universiteit van Pretoria \\ PRETORIA \\ E-pos: julian@ccnet.up.ac.za \\ jputter@telkomsa.net
}

\section{Abstract \\ Discourses of healing in a narrative-pastoral approach}

In this article fiction is used as a metaphor. True to the metaphor of fiction, this research was done through participatory action research. Conversations on the subject of healing are researched by investigating written resources and case studies as well as listening to qualified opinions. In order for healing to be widely understood, a diversity of fictional works are offered. By looking at the documented meanings of scientific disciplines and conversations it is crystal clear that healing has become a fashionable word and has apparently always been one. There are various conversations on the topic of healing, ranging from medical, theological, and even alternative perspectives. The research was done in a postmodern society, and the characteristics of this era implemented as such. A unique outcome of this dialogue is the new and fresh understanding of healing as a word which includes the person as a whole and not as a fragmented object. The culmination describes an unique discussion of healing by embracing illness as part of human existence. Brokenness is used as a point of departure in contrast with the illusion of healing.

\section{Opsomming}

\section{Diskoerse oor heling in 'n narratief-pastorale benadering}

In hierdie artikel word fiksie as metafoor benut. Eie aan die metafoor van fiksie, is deelnemende aksienavorsing die komponent wat mense deel van die navorsing maak. Diskoerse

1 Die artikel is aangebied as deel van 'n Phd.-graad onder promotorskap van Julian Müller by Praktiese Teologie, Universiteit van Pretoria in 2005. 
oor heling word nagevors, deur na verskillende verhale, geskrewe bronne, gevallestudies en kundige standpunte te luister. In die aanbieding van verhale word 'n diversiteit aangebied om die tema van heling vanuit 'n wye spektrum te verstaan. Dit is duidelik vanuit die beskrywing van diskoerse en wetenskaplike dissiplines, dat genesing een van die modewoorde van ons tyd geword het, en nog altyd was. Daar is wyd uiteenlopende diskoerse oor genesing, wat wissel van mediese-, teologiese-, en selfs alternatiewe perspektiewe. Die navorsing word binne 'n postmoderne era gedoen, terwyl die eienskappe van dié era hierin geïmplimenteer word. Heling nooi metafore soos gebrokenheid, 'n unieke lewensuitkyk, persoonlike verdieping en soeke na alternatiewe uit om betekenis aan lyding en siekte te gee. In die kulminasie van die artikel is daar 'n unieke beskrywing van heling, naamlik, siekte moet omhels word - dit is deel van die menslike bestaan. Gebrokenheid word as vertrekpunt teenoor die illusie van 'n Utopia-genesing voorgestel.

\section{Stemme}

Daar is deesdae 'n magdom boeke, artikels, TV- en radioprogramme oor die onderwerp van genesing. Daar is selfs sprake van genesing met die klem meer op die genesende krag wat by die mens ingebore is en wat ontgin moet word as 'n gegewe. In hierdie artikel word genesing gefasiliteer en gesien as deel van die normale menslike bestaan (Wildwood, 1997; Thomas, 2000; Bays, 1999). Vanuit verskillende oorde word aandag aan genesing gegee - dit wissel van geestelike genesing en mediese behandeling, tot Oosterse filosofieë. Daar is ook die wondergenesings van T.B. Joshua, Carel Bonke en Bennie Hinn. Skrywers uit verskillende religieuse agtergronde probeer elkeen beskryf hoe hierdie genesings plaasvind (Craffert, 2002; De Klerk, 1998; Marais, 1997; Sherwood, 2000). Daar is ook groeperings wat siekte soos in die Bybelse tyd aan demoniese magte toeskryf. Boeke verskyn met die oog op gesonde eetgewoontes wat genesing bevorder (Van der Merwe, 1999). Genesing word ook deur sommige mense verstaan binne die spontane genesingsprosesse wat voortdurend in die liggaam plaasvind (Sherwood, 2000; Steenkamp, 1991).

Genesing is een van die modewoorde van ons tyd (Luscombe, aangehaal in Allen et.al, 1991:45). Morris (1998:16) brei verder op die probleem uit:

The public taste for quick fixes through drugs and surgery, as deeply rooted as the taste for fast food and the fifteen minute oil 
change, helps keep the biomedical model in business at a time when a number of doctors and caregivers are coming to recognize its limitations.

Wilkinson (1980:vii) sien genesing as 'n ongesonde fokus op die mens en die minagting en swak verstaan van die Bybelse aspekte oor dié tema. Selfs die geskiedenis van die mens is deurtrek van mites, legendes en gevallestudies wat daarop wil aanspraak maak dat mense in nood hulp ontvang het. Dit is moontlik dat die meeste van die antieke terapieë ontstaan het toe die pasiënt en geneser saam in primitiewe tye na inligting gesoek het. Die mens het meestal antwoorde vir siekte en genesing gesoek deur na hulle eie wêreldbeeld te kyk. Die mens het veral demone, engele of feëtjies met hierdie temas verbind. Die visie van die primitiewe mens was beperk tot hulle lewenservaring - wat maar skraal was.

Die Westerse mens het in sy strewe na gesondheid sy hoop op medisyne geplaas. Die vraag is egter of medisyne wel die antwoord is - veral vir die probleme en siektes van die menslike psige. Die mediese wetenskap het nie in die twintigste eeu bevredigende oplossings vir die mens se psigiese toestande gebring nie. Die grootste rede hiervoor is dat die hele benadering simptoomgerig, eerder as mensgerig is (Steenkamp, 1991:140). Tans is daar 'n groot hoeveelheid inligting, filosofiese beredenerings, mediese verklarings en wyd uiteenlopende standpunte oor genesing. Pattison (1989:1) maak die volgende opmerking:

There is no area of human and religious life which is more important than that of illness and healing, yet very few of the works which spew from the presses of publishers riding the crest of a wave of popular contemporary interest do any kind of justice to the depth and complexity of the subject matter with which they have to deal. With one notable exception, the spirit of hard-headed critical exploration seems to have deserted recent Christian writing on healing and illness. It has been replaced by endless exhortations to become involved in a religious healing ministry, by testimonies from those who have experienced the power of religious healing, and by handy manuals which instruct on how to conduct religious healing.

Hierdie artikel vind nie aansluiting by die populêre stroom materiaal wat Pattison (1989:1) beskryf nie. Daar is baie stemme oor genesing, maar nie alle stemme is helend nie. Die doel van hierdie artikel is nie om 'n handige gids oor genesing daar te stel nie. In die huidige samelewing met al die verskillende siektes en diskoerse oor dié siektes, word ons genoodsaak om weer na ons wortels terug te 
keer, en opnuut na antwoorde te soek (Pattison, 1989:2; Van der Merwe, 1997:5).

\section{Heling en/of genesing?}

In die bespreking oor diskoerse van heling kom twee terme heling en genesing na vore, wat nie wisselterme is nie. Om diskoerse van heling te verstaan, is dit nodig om dié twee terme van mekaar te onderskei.

Ek sluit ten nouste by Wildwood (1997:5) aan wat aandui dat heling nie noodwendig die verdwyning van fisiese simptome is nie. Mense kan byvoorbeeld siek wees, maar heling ervaar. Heling kan onder andere die herontdekking van die kosbaarheid van lewe wees, te midde van kroniese siekte, soos byvoorbeeld kanker (Wildwood, 1997:5). Die outeur beskou heling as die manier om te dink oor siekte, waar daar nie sprake van kitsoplossings is nie. Dalk is huidige wêreldbeelde nog in die paradigma van genesing vasgevang. Willis (2000:357) ondersteun die gedagte dat daar 'n paradigmaskuif van genesing na heling gemaak moet word. Willis (2000:357) se standpunt word getabuleer en uitgebrei aangebied om die onderskeid tussen genesing en heling aan te toon:

\begin{tabular}{|l|l|}
\hline Heling & Genesing \\
\hline $\begin{array}{l}\text { Geen kitsoplossing nie, maar } \\
\text { 'n proses }\end{array}$ & Soeke na 'n kitsoplossing \\
'n Manier van dink oor siekte/- \\
toestand \\
$\begin{array}{l}\text { Wêreldbeeld nie voorwaarde } \\
\text { vir heling nie }\end{array}$ & Ontslae raak van siekte/-toestand \\
$\begin{array}{l}\text { Gebrokenheid die vertrekpunt } \\
\text { Fokus op die mens as geheel }\end{array}$ & Fosus op 'n liggaamsdeeld nodig vir genesing \\
$\begin{array}{l}\text { Ervaring van heelheid tydens } \\
\text { siekte }\end{array}$ & Afwesigheid van siekte \\
$\begin{array}{l}\text { Heling van die mens as } \\
\text { geheel }\end{array}$ & Genesing van die liggaam \\
\hline
\end{tabular}


Die betekenis van heling is wyer as dié van genesing. Neem as voorbeeld 'n kind wat deur gesinsgeweld fisiese en emosionele wonde opgedoen het. Wanneer die kind die hospitaal verlaat met verbande en steke wat die wonde toemaak, word die kind as genees beskou. Die dieper vraag oor die gesinsdinamika wat nog onveranderd voortgaan, handel oor heling. Die kind kan dus genees wees, maar het nog nie heling ervaar nie. Dieselfde gebeur met 'n volwassene wat 'n hartomleiding ondergaan het en daarna by die huis voortgaan met rook en 'n ongesonde lewenswyse (Willis, 2000:358). Henry Nouwen (1979) maak van die metafoor wounded healer gebruik, waarin hy betoog dat ons deur ons gebrokenheid, ten spyte van ons eie siekte, 'n bron van genesing vir ander kan word.

Die skrywer verkies die woord heling omdat genesing te veel met selfhelpgidse geassosieer word. By genesing is die fokus op selfgenesing, en daar is 'n onderskeid tussen geestelike genesing, geloofsgenesing en liggaamlike genesing. Genesing word sterk met voorwaardes en reëls geassiosieer, soos byvoorbeeld die nakoming van 'n spesifieke wêreldbeeld as oplossing.

Die verhaal wat Yancey (1990:16) van Claudia vertel, bevestig die idee dat mense met vooropgestelde idees oor genesing dink. Hierdie verhaal bevestig ook dat die maniere van dink oor siekte 'n uitwerking op die siek persoon het, veral ten opsigte van genesing. Claudia was met limfklierkanker in die hospitaal. Claudia het gehoop dat die Christene wat haar besoek, haar moed en hoop sou inpraat. Haar besoekers het egter meer onsekerheid as hoop gebring.

Die diaken van haar kerk het haar daarop gewys dat God besig was om haar iets te leer en dat sy iets verkeerd gedoen het waaroor God ontevrede is. ' $n$ Volgende besoeker het haarself as iemand gesien wat siek mense moes opbeur, en telkens as Claudia oor haar siekte wou praat, het die dame dit weggepraat, of met lofliedere doodgesing. 'n Volgende dame het Claudia besoek en haar meegedeel dat siekte nooit God se wil is nie, maar dat dit die duiwel is wat mense siek maak. Sy het Claudia aangemoedig om aan die belofte van genesing vas te hou en dat sy die oorwinning moes eis. Verder het sy Claudia ingelig dat sy net haar geloof moes versterk om genesing te kry.

Die volgende paar dae het Claudia met uitputtende gevolge probeer om haar geloof op só 'n vlak te kry dat sy gesond kon word. Sy het later moed opgegee. 'n Volgende dame het 'n paar boeke saamgebring wat aangetoon het dat Claudia net moes leer om God 
vir die siekte en pyn te prys. Claudia se gedagtes het egter drogbeelde van God begin skep, en sy het ervaar dat God vreugde daarin vind om mense te laat swaarkry. Claudia se pastoor het opgedaag en haar meegedeel dat sy op 'n heilige missie is en dat God 'n baie spesifieke plan vir haar lewe het. Hy het haar meegedeel dat God haar uitgekies het om swaar te kry, en dat Hy haar daarvoor sou beloon. Yancey (1990:18) vertel hoe die besoekers Claudia met hul veralgemenings oor siekte en genesing verwar het.

Heling en genesing word in hierdie artikel nie as wisselterm of kontrasterende terme gebruik nie, maar as begrippe met verskillende betekenisse.

\section{Siektes en die postmodernisme}

Een van die gevolgtrekkings wat Morris (1998:28) oor die postmodernisme maak, is die volgende: "Medical error is a serious health problem: autopsy studies have found rates of fatal miss diagnoses - that is missed diagnoses resulting in death - as high as 35-40 percent." Elke era het sy eie, spesifieke siektes (Pattison, 1989:77; Morris, 1998:50). Elke era openbaar ook 'n spesifieke reaksie van die mens op siekte (Morris, 1998:52).

Morris (1998:52) verduidelik hoe die diskoerse wat in 'n spesifieke era plaasvind, mense se uitkyk op siekte beïnvloed. Die groot plaag in die Middeleeue is deur 'n bakterie, wat op luise aangetref is, veroorsaak. Hierdie luise het ook op rotte voorgekom. In die Middeleeue was mense en rotte gereeld in kontak met mekaar as gevolg van swak lewensomstandighede. Die meeste rotte is op skepe na ander wêrelddele versprei. Die mense van die Middeleeue het egter geglo dat God hulle oor hulle sonde straf en hulle geloof toets.

They gave flesh-and-blood embodiement to the dominant values of their time and (like the medieval lepers wearing bells and confined to colonies outside the city) stood as monuments to the power of illness to define an entire era (Morris, 1998:53).

Morris (1998:56) identifiseer drie siektes as 'n uitvloeisel van postmoderne toestande: meervoudige persoonlikheidsversteuring (MPV), kroniese uitputtingsindroom, en VIGS. Baie ander toestande word egter nie genoem nie, byvoorbeeld: middelafhanklikheid, die hoë egskeidingsyfer of gesinsgeweld, om slegs enkeles te noem. Colson en Pearcy (1999:239) voeg seksuele vryheid as 'n siekte by. 
As gevolg van die verskuiwing van morele grense en seksuele vryheid, is seksuele losbandigheid een van die groot siektes van die moderne tyd. Seksuele losbandigheid gee weer aanleiding tot siektes soos VIGS en seksueel-oordraagbare toestande. Molestering en verkragting word ook hierby ingesluit, en is op sigself die verwoesters van menselewens.

Die waardes waarvolgens mense vandag leef, is subjektief (Anderson, 2001:206). Nouwen (1979:4) beskryf die verhaal van Peter, wat as voorbeeld dien van faktore waarmee mense worstel. In hierdie verhaal verduidelik Nouwen (1979:4) dat die sieke se grense van sy of haar omgewing, en die grense van fantasie en realiteit, nie duidelik is nie. Die mens word 'n gevangene in die hede.

Colson en Pearcy (1999:20) fokus op wêreldbeelde wat verduidelik waarom mense soos Peter worstel. Colson en Pearcy (1999:20) stel veral die Christendom teenoor hierdie wêreldbeelde. Aan die een kant bied die postmodernisme geleenthede tot dekonstruksie, en die soeke na unieke uitkomste. Die teenpool is egter dat essensiële waarhede van die Christelike geloof bevraagteken word. Freedman en Combs (1996:35) dui aan dat daar meer as een beskrywing van 'n gegewe realiteit is, hoewel dit nie beteken dat alles aanvaarbaar is nie. Freedman en Combs (1996:35) verstaan dekonstruksie as 'n realiteit om huidige betekenis oop te breek. Dekonstruksie bevraagteken vooropgestelde idees en help om tot 'n beter begrip van die waarde van morele keuses te kom. "Not only do we carefully examine the beliefs and values that we choose, but we invite the people who come to see us to examine their beliefs and values as well" (Freedman \& Combs, 1996:36).

\section{Dekonstruksie}

The usage of the word healing is often like that described in the scornful reply of Humpty Dumpty to Alice: 'When I use a word, it means just what I choose it to mean - neither more or less' (Wilkinson, 1998:1).

As narratiewe navorser is dit nodig om in terme van dekonstruksie te dink en diskoerse soos dit tans verstaan word, te bevraagteken. Dekonstruksie, as daar so iets is, hou met die "good reading" van tekste verband (Wolfreys, 1998:9). Die doel en betekenis van dekonstruksie is om aan te toon dat dinge soos institusies, tekste, tradisies, geloofsisteme en enige ander praktyk, nie werklik definieerbare betekenis en doel het nie; die betekenis is altyd wyer as wat dit tans is (Caputo, 1997:31). 
Caputo (1997:31) verduidelik dat die betekenis eintlik verlore gaan elke oomblik as daar betekenis aan 'n saak gegee word. 'n Betekenis of doel is volgens Caputo (1997:31) 'n manier om dinge in 'n neutedop saam te pers. Dekonstruksie soek wyer as die grense van die dop, en wil 'n versteuring in die inhoud bring. Dekonstruksie is om die neutedop oop te breek en dit wat in die binnekant versamel is, te bevraagteken (Caputo, 1997:32). Siekte en genesing is nie ten volle persoonlik, subjektief, objektief of universeel nie, maar word deur kulture gevorm en verstaan (Morris, 1998:42).

Pattison (1989:11) neem 'n dekonstruerende houding in, en nooi teoloë uit om die fokus op die verstaan van heling en siekte te plaas, en nie noodwendig op die wyse waarop die genesing gedoen word nie. Volgens Dueck (1987:240) is daar drie vertrekpunte wat in ag geneem moet word in die gesprek oor die Bybel en heling:

1. The reign of God, not modernity, is our liberating, culture-creating story which provides the resources of Western culture.

2. The church, not the helping profession, is our primary community, in that it is called to embody the ethic of the Reign of God and to discern modes of healing consistent with its story.

3. The healer as disciple, not as technician, is called to character which is shaped by the rituals and the discernment of the Christian community.

Die vertrekpunte van Dueck (1987:240) sien die skrywer as 'n dekonstruksie op huidige stemme oor genesing, asook die postmodernisme en siektes. Die vertrekpunte neem die gelowige wat soek na antwoorde oor heling en/of genesing terug na die kernwaarhede in die Skrif. 'n Verdere dekonstruksie van huidige stemme oor heling is die mening van Grenz (2000:299) wat handel oor die volgende vraag:

Why should the sincere believer continue to read the Bible, when biblical truth - correct doctrine - is more readily at hand in the latest systematic compilation offered by the skilled theologian?

Grenz (2000:299) se vraag sny diep in die "expert teologie" se wese waar die teoloog die fiktiewe funksie vervul van 'n kundige wat antwoorde het op alle moontlike vrae oor siekte en die helingsproses. Grenz (2000:299) is van mening dat die gelowige self in die Skrif na antwoorde kan soek. 
'n Verdere dekonstruksie word deur Parson (1986:155-157) voorgestel:

1. As daar oor God en genesing gepraat word, moet dit in alle nederigheid gedoen word. Elke teoloog moet bewus wees van die taal wat hy of sy gebruik, en moet onthou dat taal beperkend van aard is. Ander teoloë kan ander taal gebruik.

2. Die koninkryk van God is die ervaring van God deur die opgestane Christus, in Sy helende, vergewende en liefdevolle uitreike na die ganse mensdom. God se ervaring of betrokkenheid sit aan die hart van elke area van die menslike lewe, en sluit die sosiale, politieke en ekonomiese in.

3. Die Christelike evangelie word in eenvoudige terme aan die mens oorgedra. Geloof in God sluit gedagtes, emosies en die liggaam in. Die totale mens moet oop vir die evangelie wees.

4. Holistiese teologie is in gesprekke met ander ideologieë geïnteresseerd, sonder om die ideologie te veroordeel.

5. Die grondbeginsels van teologie moet in die helende verhouding met Jesus Christus gewortel wees. Om teologie vanuit hierdie raamwerk te beoefen, beteken om nie deur ander ideologie bedreig te voel nie, maar om in liefde daarna te luister.

6. In 'n teologie van heling moet die teoloog eerlik oor gebrokenheid en die eie ervaring van God in tye van nood wees.

7. Die rol van die Heilige Gees speel 'n belangrike rol by ' $n$ teologie.

8. Die ervaring van heling dui op die waarheid dat God intens by sy skepping betrokke is. 'n Teologie van heling verwag dat God deurbrake vir diegene bring wat gebroke is of verdeeldheid ervaar.

Die grondbeginsel is die Drie-eenheid, Vader, Seun en Heilige Gees, elk met 'n besondere werking van God. Die kern is in die evangelie van Christus opgesluit. Geloof in die evangelie vorm die basis van enige vorm van heling. Die rol van die kerk is belangrik om uitvoering aan die werk van God te gee. As vertrekpunt oor die teologie van heling geld redding deur geloof en genade. Vanuit 
daardie perspektiewe word daar in gesprek met ander dissiplines en ideologieë getree, om die groter prentjie te verstaan.

Heling sluit die totale mens in en kan nie tot 'n liggaamsdeel, emosie of gedagte gereduseer word nie. As oorkoepelende gedagte word die kernwaardes met die gedagte van gebrokenheid afgesluit. Elke mens is gebroke. Dit is 'n belangrike kernwaarde by die verstaan van heling. Deur ons gebrokenheid, kan ons 'n bron van heling vir ander word.

\section{5. "The wounded healer"}

Die manier waarop ons na pyn kyk, bepaal hoe ons pyn ervaar (Yancey, 1990:19). Yancey (1990:19) gaan verder en noem voorbeelde van hoe mense pyn ervaar - mense sterf as gevolg van kanker, hongersnood, die verlies van 'n lewensmaat, oorlog en dies meer. Pyn is egter die probleem. "The problem of pain represents a profound riddle ... They are problems like ... the loss of youth, an ulcerous throat, the prospect of a new marriage gouged by death, the paralyzing fear of the unknown" (Yancey, 1990:20).

Die gesprek oor lyding veronderstel dat die gedagtes, emosies of liggaam van die mens deur ' $n$ trauma van die een of ander aard is (Wolfreys, 1998:178). Heyns (1986:494-496) gee aandag aan die buite-Bybelse denke oor lyding. Hier word lyding as 'n illusie, 'n waarskuwing, 'n natuurlike verskynsel of 'n straf beskou en dit hou verband met die stryd tussen goed en kwaad. Laastens word lyding as ' $\mathrm{n}$ verdwynende verskynsel beskou, wat voor die tegnologiese ontwikkeling swig.

Küng (1993:92) sluit by Nouwen (1979) aan en verwys na die Suffering servant of God wat te midde van lyding moet weet dat God altyd teenwoordig is. Strukture en omstandighede is meestal die oorsaak van lyding. Heyns (1986:496) sluit ook hierby aan en fokus op die lyding van Jesus as vertrekpunt om die lyding van mense te verstaan. Die boek The Wounded Healer (Nouwen, 1979) is van toepassing op die pastor se eie verstaan van lyding en gebrokenheid.

Nouwen (1979:81) verwys na die pastor as die verwonde geneesheer. Nouwen (1979:81) vertel die verhaal waar die mens op die Messias wag en probeer die vraag beantwoord: "Hoe sal ons Verlosser kom?"

Rabbi Yoshua ben Levi came upon Elijah the prophet while he was standing at the entrance of Rabbi Simeron ben Yohai's 
cave ... He asked Elijah, 'When will the Messiah come?' Elijah replied, 'Go and ask him yourself.' 'Where is he?' 'Sitting at the gates of the city.' 'How shall I know him?'

$\mathrm{He}$ is sitting among the poor covered with wounds. The others unbind all their wounds at the same time and then bind them up again. But he unbinds one at a time and binds it up again, saying to himself, 'Perhaps I shall be needed: if so I must always be ready so as not to delay for a moment' (Nouwen, 1979:81-82).

Dié storie suggereer dat die pastor self 'n gewonde tussen ander gewondes is, maar die verskil is dat die pastor gereed is om ander gewondes te help. Die wonde van die pastor is nie 'n skande nie, maar word juis die bron van genesing van ander (Nouwen, 1979:83). Nouwen (1979:83) noem twee wonde wat pertinent in die lewe van die pastor gevind word: persoonlike eensaamheid en professionele eensaamheid. Die wond van eensaamheid is diep, omdat die beroep van 'n pastor hom uit die samelewing stoot.

Nouwen (1979:87) vra tereg: "How can wounds become a source of healing?" Hy stel dan voor dat die healing minister-metafoor (Nouwen, 1979:87) gebruik word. Hiermee word nie bedoel dat die pastor voortdurend oor eie pyn en siekte moet praat nie, maar eerder dat die pastor homself as deel van die menslike bestaan moet sien en moet besef dat sy eie wonde en siekte iets van die groter verhaal waarvan hy/sy deel is, vertel.

Nouwen (1979:89) stel dit dat die healing minister-metafoor deur die woord gasvryheid verstaan kan word. Die woord suggereer die pastor se betrokkenheid by ander, sonder dat die eie verhaal hom blind en doof maak vir die ander persoon se pyn of siekte. Dit behels onttrekking, op so 'n wyse dat die ander persoon welkom, gemaklik en spontaan voel om sy verhaal te deel. In die woorde van Nouwen (1979:91):

... we can be free to let others enter into the space created for them and allow them to dance their own dance, sing their own song and speak their own language without fear. Then our presence is no longer threatening and demanding but inviting and liberating.

Om op so 'n wyse gasvry te wees, maak dit 'n bediening van heling, want dit verwyder die illusie dat genesing aan 'n ander mens gegee kan word. Dit is helend van aard, omdat dit nie pyn en siekte wegneem nie, maar omdat dit uitnooi om die pyn en siekte oor te 
vertel. Dit bevraagteken ook die diskoers dat die pastor genesing moet bewerk, of as iemand gesien moet word wat pyn verwyder. "Perhaps the main task of the minister is to prevent people from suffering for the wrong reasons. Many people suffer because of the false supposition on which they have based their lives" (Nouwen, 1979:93).

\section{Gevolgtrekking}

Willis (2000:357) en Wildwood (1997:5) maak 'n onderskeid tussen genesing en heling. Heling is 'n meer insluitende woord as genesing. Mense het te veel voorveronderstellings as daar in terme van genesing gedink word (Yancy, 1990:16). Heling daag mense uit om nie in terme van kitsoplossings te dink nie, maar aan 'n proses. Heling kan ervaar word tydens 'n siektetoestand of krisis. As daar in terme van heling gedink word, word die gebrokenheid van die mens as vertrekpunt geneem.

\section{Geraadpleegde bronne}

ALLEN, E.A., LUSCOMBE, K.L., MEYERS, B.L. \& RAM, E.R. 1991. Health, healing and transformation: Biblical reflections on the church in ministries of healing and wholeness. USA: MARC \& World Vision International.

ANDERSON, R.S. 2001. The shape of practical theology: empowering ministry with theological praxis. Illinois: InterVarsity.

BAYS, B. 1999. The journey. London: Thorsons.

CAPUTO, J.D. 1997. Deconstruction in a nutshell: a conversation with Jacques Derrida. New York: Fordham University Press.

COLSON, C. \& PEARCY, N. 1999. How now shall we live? USA: Tynedale House.

CRAFFERT, P.F. 2002. Wat sê die Bybel regtig oor ... geloofsgenesing? Pretoria: C.B. Powell Bible Centre, Unisa.

DE KLERK, W. 1998. Die vreemde God en sy mense. Kaapstad: Human \& Rousseau.

DUECK, A.1987. Ethical contexts of healing: peoplehood and righteousness. Pastoral Psychology, 35(4):239-253.

FREEDMAN, J. \& COMBS, G. 1996. Narrative therapy: the social construction of preferred realities. New York: Norton.

GRENZ, S.J. 2000. Eschatological theology: contours of a postmodern theology of hope. Review and Expositor, 97:339-354.

HEYNS, J.A. 1986. Teologiese etiek. Pretoria: N.G. Kerkboekhandel.

KÜNG, H. 1993. Credo: the Apostles' creed explained today. London: SCM.

MARAIS, W. 1997. Gebed en genesing. Weskaap: Nasionale Boekdrukkery.

MORRIS, D.B. 1998. Illness and culture in the postmodern age. London: University of California Press.

NOUWEN, H.J.M. 1979. The wounded healer. Great Britain: Redwood Books.

PARSON, S. 1986. The challenge of Christian healing. Great Britain: WBC. 
PATTISON, S. 1989. Alive and kicking: towards a practical theology of illness and healing. London: SCM.

SHERWOOD, K. 2000. The art of spiritual healing. USA: Llewellyn.

STEENKAMP. J.O. 1991. Spontane heling intrasistemiese psigoterapie (SHIP) vir psigosomatiese simptome. Pretoria: Universiteit van Pretoria.

THOMAS, P. 2000. Alternative therapies for pregnancy and birth. USA: Element.

VAN DER MERWE, A. 1997. To health: about micronutrients, supplements, health and ageing. Kaapstad: Tafelberg.

VAN DER MERWE, A. 1999. Geluk en gesondheid: gebalanseerde genesing vir liggaam, siel, emosies en verstand. Kaapstad: Tafelberg.

WILDWOOD, C. 1997. Natural healing: practical ways to find wellbeing and inspiration. London: Judy Piatkus.

WILKINSON, J. 1980. Health and healing: studies in New Testament principles and practice. Great Britain: The Handsel Press.

WILKINSON, J. 1998. The Bible and healing: a medical and theological commentary. Great Britain: The Handsell Press.

WILLIS, R.W. 2000. Positive paradigm shifts in health care. Journal of Religion and Health, 39(4):355-365.

WOLFREYS, J. 1998. Transitions: deconstruction - Derrida. USA: St. Martin's.

YANCEY, P. 1990. Where is God when it hurts? USA: Zondervan.

\section{Kernbegrippe:}

dekonstruksie

gebrokenheid

genesing

heling

postmodernisme

siekte

\section{Key concepts:}

brokenness

cure

deconstruction

healing

postmodernism

sickness 
